\title{
MODEL PEMBELAJARAN OSBORN UNTUK MENINGKATKAN KEMAMPUAN PEMECAHAN MASALAH MATEMATIS SISWA
}

\author{
Luthfiyati Nurafifah $^{[1]}$, Elah Nurlaelah ${ }^{[2]}$, Dian Usdiyana ${ }^{[3]}$ \\ ${ }^{1}$ Universitas Wiralodra, elena.nachi@gmail.com \\ ${ }^{2}$ Universitas Pendidikan Indonesia, azela-bdg@yahoo.com \\ ${ }^{3}$ Universitas Pendidikan Indonesia, dianusdy@yahoo.com
}

\begin{abstract}
ABSTRAK
Penelitian ini bertujuan untuk mengetahui peningkatan kemampuan pemecahan masalah matematis siswa melalui penerapan Model Pembelajaran Osborn, serta membandingkannya dengan siswa yang memperoleh pembelajaran konvensional. Disamping itu, tujuan penelitian ini adalah untuk mengetahui peningkatan kemampuan pemecahan masalah matematis pada kelompok siswa berkemampuan tinggi, sedang, dan rendah. Tujuan selanjutnya adalah untuk mengetahui sikap siswa terhadap Model pembelajaran Osborn. Metode yang digunakan dalam penelitian ini adalah metode Kuasi Eksperimen dengan Desain Kelompok Kontrol Pretest dan Posttest. Populasi pada penelitian ini adalah seluruh siswa SMP N 1 Bandung. Sampel pada penelitian ini adalah dua kelas dari kelas VIII, satu kelas sebagai Kelas Eksperimen yang diberikan perlakuan, satu kelas sebagai kelas kontrol. Data penelitian diperoleh melalui tes kemampuan pemecahan masalah matematis siswa, angket siswa, dan lembar observasi. Hasil penelitian menunjukkan bahwa peningkatan kemampuan pemecahan masalah matematis siswa yang pembelajarannya menggunakan Model pembelajaran Osborn lebih baik daripada peningkatan kemampuan pemecahan masalah matematis siswa yang menggunakan pembelajaran konvensional. Terdapat perbedaan peningkatan kemampuan pemecahan masalah matematis pada siswa kelompok kemampuan tinggi, sedang dan rendah di kelas Osborn dan kelas
\end{abstract}

\section{ABSTRACT}

The purpose of this research is to find out the increase of student's mathematical problem solving competence through the implementation of Osborn Learning Model, as well as compare it with the student who earned conventional learning. In addition, the purpose of this research is to find out the increase of mathematical problem solving competence on a group of student with high, middle, and low capability. The next purpose is to find out the attitude of the students against the osborn learning model. Methods used in this research is quasi Experimenter Method with pretest and post-test Marginalized Control Design. Population on this research are all of students of VIII grades in SMPN 1 Bandung. Samples on this research are two classes of VIII grades, one class as Experimental Class and the other one as control class. Research data obtained through the test of student's mathematical problem solving competence, questionnaire, and observation sheets. The result of this research shows that the increasing of student's mathematical problem solving competence with Osborn Learning Model better than the increasing of student's mathematical problem solving competence with conventional learning. There are differences in the increasing competence on the groups of high capability, middle capability and low capability in osborn class and conventional class. In general, the students give a positive attitude against Osborn Learning Model. 
konvensional. Secara umum, siswa memberikan sikap yang positif terhadap model pembelajaran Osborn.

Kata Kunci: Model Pembelajaran Osborn, Pemecahan Masalah

Matematis.

$\begin{array}{ll}\text { Keywords: } & \begin{array}{l}\text { Osborn Learning } \\ \text { Mathematical } \\ \text { Solving. }\end{array}\end{array}$

\section{How to Cite: Nurafifah, L., Nurlaelah, E., \& Usdiyana, D. (2016). Model Pembelajaran Osborn untuk Meningkatkan Kemampuan Pemecahan Masalah Matematis Siswa. Mathline: Jurnal Matematika dan Pendidikan Matematika, Vol.1, No.2, 93-102.}

\section{PENDAHULUAN}

Matematika merupakan salah satu mata pelajaran yang wajib dipelajari, terutama di sekolah-sekolah formal. Mengingat begitu pentingnya peran matematika dalam ilmu pengetahuan dan teknologi, maka matematika perlu dipahami dan dikuasai oleh segenap lapisan masyarakat. Pada BSNP (2006), mata pelajaran matematika dalam Kurikulum Tingkat Satuan Pendidikan (KTSP) bertujuan agar siswa:

1. Memahami konsep matematika, menjelaskan keterkaitan antar konsep dan mengaplikasikan konsep atau algoritma, secara luwes, akurat, efisien, dan tepat, dalam pemecahan masalah;

2. Menggunakan penalaran pada pola dan sifat, melakukan manipulasi matematika dalam membuat generalisasi, menyusun bukti, atau menjelaskan gagasan dan pernyataan matematika;

3. Memecahkan masalah yang meliputi kemampuan memahami masalah, merancang model matematika, menyelesaikan model dan menafsirkan solusi yang diperoleh;

4. Mengkomunikasikan gagasan dengan simbol, tabel, diagram, atau media lain untuk memperjelas keadaan atau masalah;

5. Memiliki sikap menghargai kegunaan matematika dalam kehidupan, yaitu memiliki rasa ingin tahu, perhatian, dan minat dalam mempelajari matematika, serta sikap ulet dan percaya diri dalam pemecahan masalah (Veragawati, 2009).

Berdasarkan tujuan KTSP tersebut, tampak jelas bahwa salah satu tujuan dari pembelajaran matematika adalah agar siswa memiliki kemampuan pemecahan masalah. Kemampuan ini sangat berguna bagi siswa pada saat mendalami matematika maupun dalam 
kehidupan sehari-hari. Bell (1978) menyatakan bahwa pemecahan masalah merupakan proses yang paling pokok dalam matematika.

Dalam kenyataannya, kemampuan pemecahan masalah siswa pada saat ini masih rendah. Sebagaimana penelitian yang dilakukan Muncarno (Suhendra, 2005) ditemukan beberapa kesulitan dalam memahami permasalahan yang terdapat dalam soal matematika, diantaranya belum terbiasa dengan bentuk soal pemecahan masalah. Sedangkan hasil penelitian Animan (Suhendra, 2005) mengungkapkan bahwa kemampuan siswa dalam mengubah soal matematika berbentuk soal cerita ke bentuk kalimat matematika tergolong rendah, yaitu dengan rata-rata 44,67\%. Selanjutnya Loviana (Suhendra, 2005) mengungkapkan bahwa persentase kesalahan sistematis siswa dalam menyelesaikan soal cerita masih sangat tinggi yaitu 90,48\%.

Berdasarkan uraian di atas dan mengingat pembelajaran matematika yang terlaksana masih cenderung teacher centered, serta siswa dibiarkan puas dengan hanya mengerjakan soal-soal rutin, maka diperlukan suatu model pembelajaran yang student centered, merangsang, mendorong, dan memfasilitasi siswa untuk bisa menyelesaikan soal-soal tidak rutin yang pada akhirnya dapat meningkatkan kemampuan pemecahan masalah matematis siswa. Kebutuhan akan model pembelajaran ini mendorong berbagai pihak untuk melakukan pengujian berbagai model pembelajaran yang dapat meningkatkan kemampuan pemecahan masalah matematis. Salah satu model pembelajaran yang dapat diujicobakan untuk meningkatkan kemampuan pemecahan masalah matematis adalah Model pembelajaran Osborn.

Model pembelajaran Osborn adalah suatu model pembelajaran dengan menggunakan metode atau teknik brainstorming. Teknik brainstorming dipopulerkan oleh Alex F. Osborn dalam bukunya Applied Imagination. Istilah brainstorming mungkin istilah yang paling sering digunakan, tetapi juga merupakan teknik yang paling tidak banyak dipahami. Orang menggunakan istilah brainstroming untuk mengacu pada proses untuk menghasilkan ide-ide baru atau proses untuk memecahkan masalah.

Teknik brainstorming (Guntar, 2008) adalah teknik untuk menghasilkan gagasan yang mencoba mengatasi segala hambatan dan kritik. Kegiatan ini mendorong munculnya banyak gagasan, termasuk gagasan yang nyeleneh, liar, dan berani dengan harapan bahwa gagasan tersebut dapat menghasilkan gagasan yang kreatif. Brainstorming sering digunakan dalam diskusi kelompok untuk memecahkan masalah bersama. Brainstorming juga dapat digunakan 
secara individual. Sentral dari brainstorming adalah konsep menunda keputusan. Dalam dunia industri, metode brainstorming ini banyak digunakan dalam rangka menyelesaikan suatu masalah. Osborn mengatakan bahwa dalam memecahkan masalah (Cahyono, 2007), terdapat 3 prosedur yang ditempuh, yaitu:

1. Menemukan fakta, melibatkan penggambaran masalah, mengumpulkan dan meneliti data dan informasi yang bersangkutan.

2. Menemukan gagasan, berkaitan dengan memunculkan dan memodifikasi gagasan tentang strategi pemecahan masalah.

3. Menemukan solusi, yaitu proses evaluatif sebagai puncak pemecahan masalah.

Dahlan (2006) mengemukakan tahapan-tahapan pembelajaran untuk memulai brainstorming, antara lain:

1. Tahap orientasi (Guru menyajikan masalah atau situasi baru kepada siswa)

2. Tahap analisa (Siswa merinci bahan yang relevan atas masalah yang ada, dengan kata lain, siswa mengidentifikasi masalah)

3. Tahap hipotesis (Siswa dipersilahkan untuk mengungkapkan pendapat terhadap situasi atau permasalahan yang diberikan)

4. Tahap pengeraman (Siswa bekerja secara mandiri dalam kelompok untuk membangun kerangka berfikirnya)

5. Tahap sintesis (Guru membuat diskusi kelas, siswa diminta mengungkapkan pendapatnya atas permasalahan yang diberikan, menuliskan semua pendapat itu, dan siswa diajak untuk berfikir manakah pendapat yang terbaik)

6. Tahap verifikasi (Guru melakukan pemilihan keputusan terhadap gagasan yang diungkapkan siswa sebagai pemecahan masalah terbaik).

Ruseffendi (1998) mengemukakan bahwa masalah dalam matematika adalah suatu persoalan yang ia sendiri mampu menyelesaikannya tanpa menggunakan cara atau algoritma yang rutin. Suatu persoalan merupakan masalah bagi siswa bila; 1) Siswa belum mempunyai prosedur atau algoritma tertentu untuk menyelesaikan; 2) Siswa mampu menyelesaikan, dan 3) Siswa memiliki niat menyelesaikannya. Hayes (Veragawati, 2009) mengemukakan bahwa problem atau masalah bagi seseorang adalah suatu kesenjangan antara dua pengertian yang dimilikinya dan ia pun tak tahu cara mengatasinya. 
Adapun mengenai pemecahan masalah, terdapat banyak interpretasi tentang pemecahan masalah dalam matematika, diantaranya adalah Polya (Veragawati, 2009) mengemukakan ada empat aspek atau langkah yang dapat ditempuh dalam pemecahan masalah, yaitu:

1. Memahami masalah

2. Membuat rencana

3. Melakukan perhitungan

4. Memeriksa kembali hasil yang diperoleh.

Lebih spesifik, Sumarmo (Veragawati, 2009) mengartikan pemecahan masalah sebagai kegiatan menyelesaikan soal cerita, menyelesaikan soal yang tidak rutin, mengaplikasikan matematika dalam kehidupan sehari-hari atau keadaan lain dan membuktikan atau menciptakan atau menguji konjektur.

Farida (Mulia, 2010) mengemukakan indikator yang digunakan dalam pemecahan masalah, antara lain:

1. Mengidentifikasi unsur yang diketahui, yang ditanyakan, dan kecukupan unsur yang diperlukan;

2. Merumuskan masalah matematika (menyusun model matematika);

3. Menerapkan strategi penyelesaian berbagai masalah (baik yang sejenis maupun masalah baru) di dalam atau di luar matematika;

4. Menjalankan atau menginterpretasi hasil sesuai dengan permasalahan asal;

5. Menggunakan matematika secara bermakna.

Kemampuan pemecahan masalah adalah kemampuan siswa untuk memecahkan masalah yang diberikan. Berdasarkan uraian di atas, Penulis mendefinisikan kemampuan pemecahan masalah matematis adalah kemampuan siswa dalam mengidentifikasi masalah matematika, merencanakan penyelesaian, melakukan perhitungan, dan memeriksa kembali hasil yang telah diperoleh. Berdasarkan uraian di atas, penelitian ini bertujuan untuk mengetahui :

1. Peningkatan kemampuan pemecahan masalah matematis siswa melalui penerapan Model Pembelajaran Osborn dan membandingkannya dengan siswa yang memperoleh pembelajaran konvensional.

2. Peningkatan kemampuan pemecahan masalah matematis pada kelompok siswa berkemampuan tinggi, sedang, dan rendah.

3. Sikap siswa terhadap Model pembelajaran Osborn. 


\section{METODE PENELITIAN}

Penelitian yang dilakukan adalah penelitian eksperimen. Namun, pengambilan sampel pada penelitian ini tidak secara acak siswa, tetapi acak kelas. Peneliti harus menerima kondisi dua kelas yang diperoleh secara acak tersebut (kelas eksperimen dan kelas kontrol). Sehingga, berdasarkan metodenya, penelitian ini adalah penelitian kuasi eksperimen (Ruseffendi, 2005).

Desain penelitian yang digunakan pada penelitian ini adalah desain kelompok kontrol pre-test (Tes Awal) dan post-test (Tes Akhir). Dalam penelitian ini, terdapat dua kelompok yakni kelas eksperimen dan kelas kontrol. Kelas eksperimen diberikan perlakuan khusus, dalam hal ini, Model pembelajaran Osborn. Sementara kelas kontrol menggunakan pembelajaran konvensional. Sebelum diberikan perlakuan, kedua kelas tersebut diberikan tes awal. Setelah perlakuan selesai diberikan, dilakukan tes akhir. Adapun desain penelitian ini (Ruseffendi, 1998) digambarkan sebagai berikut :

$\mathrm{A} \mathrm{O}_{1} X \mathrm{O}_{2}$

$\mathrm{A} \mathrm{O}_{1} \quad \mathrm{O}_{2}$

Keterangan: A : Menunjukkan pengelompokan subjek secara acak kelas.

$\mathrm{O}_{1}$ : Tes awal (Pre-Test)

$\mathrm{O}_{2}$ : Tes akhir (Post-Test)

$X$ : Pembelajaran matematika dengan menggunakan model pembelajaran Osborn

Penelitian ini dilakukan di kelas VIII SMP N 1 Bandung. Peneliti memilih siswa SMP sebagai subjek penelitian dikarenakan dalam perkembangan perilaku kognitifnya, siswa SMP telah mampu berpikir formal. Oleh karena itu, populasi dari penelitian ini adalah seluruh siswa kelas VIII SMP N 1 Bandung. Dari lima kelas yang ditawarkan, dipilih dua kelas secara acak untuk dijadikan kelas eksperimen dan kelas kontrol. Dengan sampling sederhana, terpilihlah kelas VIII-6 sebagai kelas eksperimen dan kelas VIII-5 sebagai kelas kontrol. Sehingga, sampel dari penelitian ini adalah kelas VIII-6 dan kelas VIII-5.

\section{HASIL DAN PEMBAHASAN}

Analisis dilakukan terhadap data tes awal, tes akhir, dan indeks gain (gain ternormalisasi). Analisis terhadap data tes awal menghasilkan kesimpulan bahwa kelas 
eksperimen dan kelas kontrol memiliki kemampuan awal yang homogen. Analisis terhadap tes akhir memberikan kesimpulan bahwa kemampuan pemecahan masalah matematis siswa kelas eksperimen (yang menggunakan Model pembelajaran Osborn) lebih baik daripada kemampuan pemecahan masalah matematis siswa kelas kontrol (yang menggunakan pembelajaran konvensional. Analisis terhadap data gain ternormalisasi menghasilkan kesimpulan bahwa peningkatan kemampuan pemecahan masalah matematis siswa yang menggunakan Model pembelajaran Osborn lebih baik daripada peningkatan kemampuan pemecahan masalah matematis siswa yang memperoleh pembelajaran konvensional.

Analisis selanjutnya adalah analisis terhadap kelompok siswa berkemampuan tinggi, sedang, dan rendah di kelas eksperimen dan kelas kontrol. Hasil analisis menunjukkan bahwa terdapat perbedaan peningkatan kemampuan pemecahan masalah matematis pada siswa berkemampuan tinggi, sedang dan rendah pada siswa yang menggunakan Model pembelajaran Osborn dan siswa yang menggunakan pembelajaran konvensional. Perbedaan yang signifikan terjadi antara:

1. Kelompok kemampuan rendah konvensional dengan kelompok kemampuan rendah Osborn

2. Kelompok kemampuan rendah konvensional dengan kemampuan tinggi Osborn

3. Kelompok kemampuan tinggi konvensional dengan kemampuan tinggi Osborn, dan

4. Kelompok kemampuan sedang konvensional dengan kemampuan tinggi Osborn

Analisis terhadap angket skala sikap siswa menghasilkan kesimpulan bahwa siswa memberikan respon yang positif terhadap Model pembelajaran Osborn. Siswa menyadari akan peranan dan penerapan matematika dalam kehidupan sehari-hari.

\section{Deskripsi Pembelajaran dengan Model Pembelajaran Osborn}

Pembelajaran matematika dengan menggunakan Model pembelajaran Osborn diawali dengan penyampaian tujuan pembelajaran, pemberian motivasi, dan penyampaian model pembelajaran yang akan digunakan. Pembelajaran dilanjutkan dengan pemberian apersepsi oleh guru dengan tanya jawab singkat mengenai materi yang telah lalu (luas bangun datar).

Guru membagi siswa ke dalam beberapa kelompok yang terdiri atas 5-6 siswa dalam setiap kelompok. Guru membagikan LKS untuk tiap kelompok. Guru menyampaikan situasi yang ada pada LKS secara umum. Siswa memperhatikan arahan yang diberikan guru. Tahapan ini disebut Tahap Orientasi. LKS diawali dengan masalah kontektual yang 
dilengkapi dengan tahapan-tahapan pengisian yang akan menuntun siswa membangun konsep matematika.

Siswa di tiap kelompok mengidentifikasi setiap masalah yang diberikan dalam LKS, mengumpulkan data yang bisa diperoleh dari situasi yang diberikan. Siswa berdiskusi dengan teman sekelompok. Tahapan ini disebut Tahap Analisis.

Setelah dapat mengidentifikasi masalah yang diberikan, siswa mengungkapkan dan menuliskan gagasannya untuk menyelesaikan permasalahan yang diberikan. Gagasan siswa tersebut ditulis dalam kolom pendapat. Siswa menuliskan gagasannya secara bergantian untuk suatu permasalahan. Tahap ini disebut Tahap Hipotesis.

Siswa bekerja secara individual dalam kelompok masing-masing untuk merumuskan pemecahan masalah. Setelah itu, semua gagasan pemecahan masalah dari masing-masing siswa dituliskan dan didiskusikan dalam kelompok masing-masing. Guru memantau jalannya diskusi di tiap kelompok.Tahapan ini disebut Tahap Pengeraman.

Guru membuat diskusi kelas, perwakilan masing-masing kelompok mengungkapkan dan menuliskan gagasan penyelesaian masalah yang paling tepat menurut masing-masing kelompok. Dari beberapa gagasan yang ada, siswa diajak untuk berfikir, manakah gagasan terbaik. Seringkali muncul gagasan yang berbeda untuk satu masalah. Hal ini dikarenakan perbedaan cara berfikir dan kehati-hatian siswa dalam menyelesaikan masalah. Namun perbedaan gagasan inilah yang menjadikan siswa ingat dan tidak melakukan kesalahan di waktu yang akan datang. Tahapan ini disebut Tahap Sintesis.

Setelah siswa mempresentasikan hasil diskusi kelompoknya, dan ketika terdapat perbedaan pendapat, guru memutuskan gagasan mana yang terbaik yang diambil dan menghasilkan jawaban yang benar. Tahapan ini disebut Tahap Verifikasi. Semua tahapan kegiatan inti pembelajaran dengan Model pembelajaran Osborn telah dilalui. Guru membimbing siswa untuk membuat rangkuman materi pembelajaran yang telah dibahas pada hari tersebut. Kemudian siswa diberikan Pekerjaan Rumah (PR) untuk lebih mengasah pemahaman siswa akan soal-soal pemecahan masalah. Siswa pun diminta membaca materi yang akan disampaikan pada pertemuan selanjutnya. Namun, karena siswa tidak memiliki buku pegangan, umumnya siswa tidak membaca materi yang diajarkan dengan alasan tidak memiliki buku paket. Kendatipun demikian, siswa dapat mengikuti pembelajaran dengan baik dan benar-benar serius dalam melaksanakan tiap tahap pembelajaran. 
Kelebihan Model pembelajaran Osborn adalah siswa dapat mengkonstruk pengetahuannya sendiri, mengeluarkan pendapat dengan bebas tanpa takut disalahkan, memberikan kesempatan berdiskusi dan bekerjasama dengan teman sekelas. Kekurangan Model pembelajaran Osborn adalah membutuhkan banyak waktu untuk berdiskusi dan mempresentasikan hasil diskusi kelompok, sehingga dibutuhkan pengaturan waktu yang lebih efektif dan efisien. Selain itu, model pembelajaran ini dapat diterapkan pada materi yang pengetahuan dasarnya sudah diberikan pada siswa. Siswa hanya harus sedikit mengonstruk pengetahuan baru dari pengetahuan yang sudah diperoleh.

\section{KESIMPULAN}

Berdasarkan hasil analisis data dan pembahasan pada keseluruhan tahap penelitian, diperoleh kesimpulan bahwa:

1. Peningkatan kemampuan pemecahan masalah matematis siswa yang menggunakan Model pembelajaran Osborn lebih baik dari peningkatan kemampuan pemecahan masalah matematis siswa yang menggunakan pembelajaran konvensional.

2. Terdapat perbedaaan peningkatan kemampuan pemecahan masalah matematis pada kelompok siswa berkemampuan tinggi, sedang, dan rendah pada siswa yang pembelajarannya menggunakan Model pembelajaran Osborn dan pembelajaran konvensional. Perbedaan yang signifikan terjadi antara rata-rata gain ternormalisasi kelompok kemampuan rendah konvensional dengan kelompok kemampuan rendah Osborn, kelompok kemampuan rendah konvensional dengan kemampuan tinggi Osborn, kelompok kemampuan tinggi konvensional dengan kemampuan tinggi Osborn, dan kelompok kemampuan sedang konvensional dengan kemampuan tinggi Osborn. Walaupun kelompok kemampuan sedang di kelas Osborn memiliki peningkatan yang paling kecil di kelas Osborn, namun peningkatan ini masih lebih besar dari peningkatan kelompok sedang kelas konvensional (yang memiliki peningkatan terbesar di kelas konvensional).

3. Siswa memberikan respon yang positif terhadap Model pembelajaran Osborn. Siswa merasakan manfaat yang berarti setelah mengikuti pembelajaran dengan Model pembelajaran Osborn. Siswa menjadi paham tentang aplikasi dan kegunaan matematika dalam kehidupan sehari-hari. 


\section{DAFTAR PUSTAKA}

Bell, F. (1978). Teaching and Learning Mathematics (In Secondary School). Lowa: WC. Brown Co.

BSNP. (2006). Draft Final Kurikulum Tingkat Satuan Pendidikan Standar Kompetensi Mata Pelajaran Matematika Sekolah Menengah Pertama dan Madrasah Tsanawiyah. Jakarta: Badan Standar Nasional Pendidikan.

Cahyono, A. N. (2007). Pengembangan Model Creative Problem Solving berbasis Teknologi dalam Pembelajaran Matematika di SMA. 29 April 2010. http://www.adinegara.blogspot.com/.

Dahlan, A. (2006). Pengaruh Model Pembelajaran Osborn terhadap Kemampuan Pemahaman Matematik Siswa. Skripsi FPMIPA UPI: Tidak diterbitkan.

Guntar, A. (2008). Definisi Masalah dan Sasaran dalam Pemecahan Masalah. 29 April 2010. www.slideshare.net/.../pemecahan-masalah-pengambilan-keputusan - Amerika Serikat.

Mulia, A. (2010). Pembelajaran Matematika dengan Menggunakan Pendekatan Problem Posing untuk Meningkatkan Kemampuan Pemecahan Masalah Matematis Siswa SMP. Skripsi FPMIPA UPI: Tidak diterbitkan.

Ruseffendi, E.T. (1998). Pengajaran Matematika Modern untuk Orang Tua Murid, Guru, dan SPG. Bandung: Tarsito.

Ruseffendi, E.T. (2005). Dasar-dasar Penelitian Pendidikan dan Bidang Non-Eksakta Lainnya. Bandung: Tarsito.

Suhendra. (2005). Pembelajaran Berbasis Masalah dalam Kelompok Kecil untuk Mengembangkan Kemampuan Siswa SMA pada Aspek Problem Solving Matematik. Tesis SPs UPI: Tidak diterbitkan.

Veragawati. (2009). Pengaruh Implementasi Strategi Working Backward terhadap Peningkatan Kemampuan Pemecahan Masalah Matematika siswa SMP. Skripsi FPMIPA UPI: Tidak diterbitkan. 